\title{
BIOFILMS FORMATION AND PREVENTION ON URINARY CATHETERS: A BIBLIOMETRIC ANALYSIS
}

\author{
FORMAÇÃO E PREVENÇAO DE BIOFIOMES EM CATETERES URINÁRIOS: UMA \\ ANÁLISE BILIOMÉTRICA
}

\author{
Odinéa Maria Amorim BATISTA ${ }^{1}$; Rachel Maciel MONTEIRO²; \\ Marinila Buzanelo MACHADO ${ }^{3}$; Pedro Castania Amadio DOMINGUES ${ }^{4}$; Evandro \\ WATANABE ${ }^{5}$; Denise de ANDRADE ${ }^{6}$; Maria Eliete Batista MOURA ${ }^{7}$
}

1. Enfermeira, Doutora e Professora Adjunta da Universidade Federal do Piauí - UFPI, Teresina, PI, Brasil. oenf@uol.com.br; 2. Bióloga e Doutoranda pelo Programa de Pós-Graduação em Enfermagem Fundamental da Escola de Enfermagem de Ribeirão Preto, Universidade de São Paulo - USP, Ribeirão Preto, SP, Brasil; 3. Biomédica e Doutoranda pelo Programa de Pós-Graduação em Enfermagem Fundamental da Escola de Enfermagem de Ribeirão Preto - USP, Ribeirão Preto, SP, Brasil; 4. Biomédico e Mestrando pelo Programa de Pós-Graduação em Enfermagem Fundamental da Escola de Enfermagem de Ribeirão Preto - USP, Ribeirão Preto, SP,

Brasil; 5. Farmacêutico-Bioquímico, Doutor e Professor Associado do Departamento de Odontologia Restauradora da Faculdade de Odontologia de Ribeirão Preto - USP, Ribeirão Preto, SP, Brasil. 6. Enfermeira, Doutora e Professora Associada do Departamento de Enfermagem Geral e Especializada da Escola de Enfermagem de Ribeirão Preto - USP, Ribeirão Preto, SP, Brasil; 7. Enfermeira, Doutora e Professora Titular da UFPI, Teresina, PI, Brasil. Network in Exposome Human and Infectious Diseases (NEHID).

\begin{abstract}
To map the scientific production about biofilms formation and prevention on urinary catheters. It is a bibliometric, exploratory, and descriptive research performed in Web of Science ${ }^{\mathrm{TM}}$, in three stages, and utilizing HistCite ${ }^{\mathrm{TM}}$ software. In this regard, descriptors "Biofilm*" AND "Urinary Catheter*" were utilized within the period between 1945 and 2016. A total of 329 articles about biofilm on urinary catheter were found from 1985 to 2016. These articles were written by 1,262 authors from 452 institutions located in 50 countries. The relation among the 15 selected articles, the most impacting ones, evidences the existence of experimental researches; most of them was in vitro. The control of biofilm formation on urinary catheters remains as a major challenge in the health area, because new ways are necessary to improve the prevention and minimization of this phenomenon.
\end{abstract}

KEYWORDS: Biofilms. Bibliometrics. Urinary Catheters.

\section{INTRODUCTION}

Health care-related infection (HCI) has a direct impact on the safety and quality of health care. It may involve the individual in institutions of hospital and / or outpatient care, as a day or home hospital and may be associated with some assistance procedure (therapeutic or diagnostic) (FURLAN et al, 2019a; MATOS et al, 2018; FURLAN et al, 2019b; SOUSA et al, 2017b).

Among the HCI, urinary tract infection (UTI) is common in the Health Care Facility (HCF) and is often related to the use of a urinary catheter. Approximately $50 \%$ of patients with a short-term urinary catheter (less than 7 days) acquire infections during this period. For patients with a long-term catheter (28 days or more) the risk of infection is $100 \%$ (MATOS et al, 2018; FURLAN et al, 2019b).

The presence of biofilm in invasive devices, such as urinary catheters, is still an unmanaged threat. We highlight the importance of structural and organizational biofilm research in order to understand the most intrinsic cellular and molecular characteristics during its development (BATISTA et al, 2018; SANTOS-JUNIOR et al, 2018).

In this context, the analysis of the scientific production about biofilm in a urinary catheter becomes necessary, since it is through this that the understanding of this phenomenon becomes possible. Therefore, the importance of conducting a bibliometric research that is characterized by the survey of the documents published in the various research areas is justified.

The aim of this research was to map the scientific production in the ISI Web of Knowledge / Web of Science ${ }^{\mathrm{TM}}$ main collection regarding the formation and prevention of biofilms in urinary catheters, aiming to identify their main contributions to the subject under analysis and their interrelationships in citations identified between these texts.

\section{MATERIAL AND METHOD}

This is a bibliometric, exploratory and descriptive research. This type of research uses 
quantitative and statistical techniques that concentrate efforts on indicators of academic activity, including productions measured by publications and citations in international databases (CRONIN, 2001). Its relevance as a technique for collecting and analyzing data has been corroborated as one of the argumentative sources in the search for research investment resources in academic rankings (DIEM, WOLTER, 2013). In order to perform bibliometric research, the selection of the database to be used is very important and must be consistent with the research objective and the results (KOSKINEN et al, 2008). The three steps adopted in this bibliometric survey were: definition of the database and the criteria used for the collection; collection in the database; representation and analysis of the data collected. They are similar to those used in the scientific literature (SANTOS et al, 2011ab; SANTOS et al, 2014).

The database used for the search was the ISI Web of Knowledge / Web of Science ${ }^{\mathrm{TM}}$ due to its "academic recognition for being considered one of the most comprehensive journal bases of several areas of scientific knowledge" (SANTOS et al., 2011ab). We used the total search period available in this database, the full years from 1945 to 2016, in order to include all references (from the oldest to the most recent). In this way, the following search terms were defined: "Biofilm *" AND "Urinary Catheter *". The use of quotation marks indicates the exact representation of terms with more than one word and asterisks, the plural possibilities of descriptors. The collection was performed from the search of these terms in the "topic" that represents the title of the articles, abstracts, keywords of the author and keywords created (KeyWords Plus).

After the search, the articles for the bibliometric analysis proposed in this research were identified. There was no refinement filter for knowledge areas, countries or research languages, thus covering all records of publications that had the two terms in association.

The data were exported to the bibliometric analysis software HistCite ${ }^{\mathrm{TM}}$, in order to organize the information. The following were analyzed: the annual evolution of publications; the journals with the greatest number of records; the authors with more publications; the number of articles distributed by author's country of origin; the most cited articles in the ISI Web of Knowledge / Web of Science ${ }^{\mathrm{TM}}$ (Global) and those most cited in the set of selected articles (Local). These organized data are presented in the results section in the form of tables, graph and figure.
In addition to these data generated by the software, the texts of the Top 10 researches that compose the two most cited groups of papers were selected for discussion in this study: articles that received more quotations from other works in the entire ISI database Web of Knowledge / Web of Science $^{\mathrm{TM}}$ (Global Citation Score - GCS) and articles that received more citations from the work of the selection group of this bibliometric survey (Local Citation Score LCS).

\section{RESULTS}

The bibliometric analysis revealed 329 articles about biofilm formation in urinary catheters between 1985 and 2016. These articles were published in 167 different journals indexed to the Web of Science ${ }^{\mathrm{TM}}$, as well as written by 1,262 authors related to 452 institutions located in 50 countries. For the achievement of these articles, 8,522 references with an average of approximately 26 references per article were used.

The first publication record dates back to 1985 (one article). There were alternations of number of searches with a period without records (1986-1990) followed by a gradual increase, mainly, from 2012. The highest number of publications occurred in the year 2016 (total of 46), indicating that the interest in the issue of biofilm formation in urinary catheters tends to continue growing and the subject is current and relevant. The evolution of the number of publications distributed by the years of the records can be observed in Figure 1.

The total number of publications was organized through corresponding journals, and Table 1 presents these results.

The journals with the highest number of publications were: "Antimicrobial Agents and Chemotherapy"; "Journal of Urology" and "International Journal of Antimicrobial Agents" with 15, 11 and 10 records, respectively. To present the journals with the greatest impact, an index from the division of the number of citations by the number of published works, indicating the Journal of Antimicrobial Chemotherapy as the one with the highest index (74.3) was defined. This index and the indication of impact journals are relevant for researchers and research centers in the area by mapping the academic journals that publish the most and the ones that receive more quotations from other researches.

The total number of authors with the highest number of publications was organized by the number of articles, link institution and corresponding countries. Among the 1,262 authors, 
Table 2 indicates the 10 with the highest number of publications.

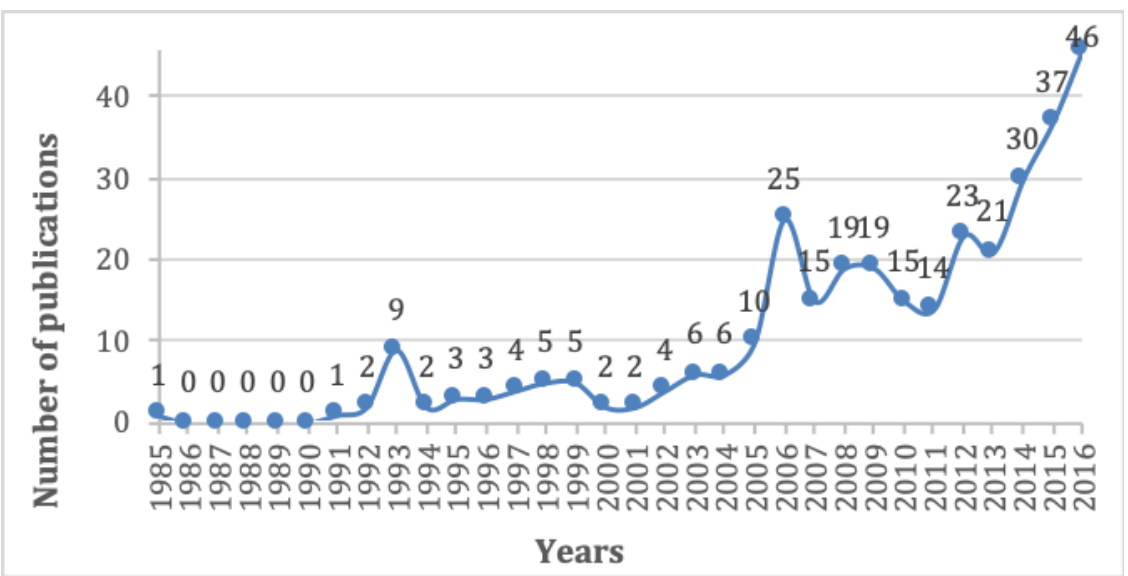

Figure 1. Distribution of publications on biofilm formation in urinary catheters (1985-2016).

Table 1. Distribution of journals in relation to the quantity of articles, citations and quotations by quantity of published articles (1985-2016).

\begin{tabular}{|c|c|c|c|}
\hline Periodicals & $\begin{array}{l}\text { Number of } \\
\text { Articles }\end{array}$ & Citations & $\begin{array}{l}\text { Citations / } \\
\text { Amount }\end{array}$ \\
\hline Antimicrobial Agents and Chemotherapy & 15 & 939 & 62,6 \\
\hline Journal of Urology & 11 & 142 & 12,9 \\
\hline International Journal of Antimicrobial Agents & 10 & 254 & 25,4 \\
\hline Journal of Medical Microbiology & 9 & 290 & 32,2 \\
\hline Fems Immunology and Medical Microbiology & 8 & 338 & 42,2 \\
\hline Bju International & 7 & 78 & 11,1 \\
\hline $\begin{array}{l}\text { Journal of Biomedical Materials Research Part B-Applied } \\
\text { Biomaterials }\end{array}$ & 7 & 70 & 10 \\
\hline Biofouling & 6 & 73 & 12,1 \\
\hline Journal of Antimicrobial Chemotherapy & 6 & 446 & 74,3 \\
\hline Urological Research & 6 & 181 & 30,1 \\
\hline
\end{tabular}

Table 2. Authors with the highest number of publications (1985-2016).

\begin{tabular}{|c|c|c|c|}
\hline Authors & $\begin{array}{l}\text { Number of } \\
\text { Articles }\end{array}$ & Affiliation (Institution) & Country \\
\hline Stickler DJ & 34 & Cardiff School of Biosciences, Cardiff University & $\begin{array}{l}\text { United } \\
\text { Kingdom }\end{array}$ \\
\hline Darouiche RO & 8 & $\begin{array}{l}\text { Center for Prostheses Infections and Infectious Disease } \\
\text { Section }\end{array}$ & United States \\
\hline Stickler DJ & 8 & Univ Wales Coll Cardiff & $\begin{array}{l}\text { United } \\
\text { Kingdom }\end{array}$ \\
\hline Trautner BW & 7 & Veterans Affairs Medical Center & United States \\
\hline Jones DS & 6 & The Queen's University of Belfast & $\begin{array}{l}\text { United } \\
\text { Kingdom }\end{array}$ \\
\hline Morris NS & 6 & Cardiff University & $\begin{array}{l}\text { United } \\
\text { Kingdom }\end{array}$ \\
\hline Pascual A & 6 & Univ Seville & United States \\
\hline Reid G & 6 & Univ Toronto & Canada \\
\hline Feneley RCL & 5 & Southmead Gen Hosp & $\begin{array}{l}\text { United } \\
\text { Kingdom }\end{array}$ \\
\hline Jones BV & 5 & Univ Wales Coll Cardiff & $\begin{array}{l}\text { United } \\
\text { Kingdom }\end{array}$ \\
\hline
\end{tabular}


Table 3 indicates the 10 linking countries of the studies, with the predominance of research originating in the United States, followed by the United Kingdom and Canada.

Table 3. Number of articles by country of origin of authors' bond institutions.

\begin{tabular}{ll}
\hline Country & Number of articles \\
\hline U.S & 82 \\
UK & 75 \\
Canada & 24 \\
India & 19 \\
Spain & 17 \\
Germany & 14 \\
Italy & 14 \\
Poland & 14 \\
Denmark & 9 \\
Portugal & 9 \\
\hline
\end{tabular}

Figure 1 shows the Top 10 relationship between the most cited articles in the ISI Web of Science ${ }^{\mathrm{TM}}$ database in the GCS and LCS groups, as follows: the number of citations and the relationships between these works, represented by lines connecting the circles, indicate the most representative surveys on the subject, presenting seminal and later works that were also very referenced. Each circle contains a number that indicates the article, that numbering referring to the order that the article appears in HistCite ${ }^{\mathrm{TM}}$. Moreover, its size refers to the relevance and quantity of citations. The arrows indicate the relations between the works and said quotations.

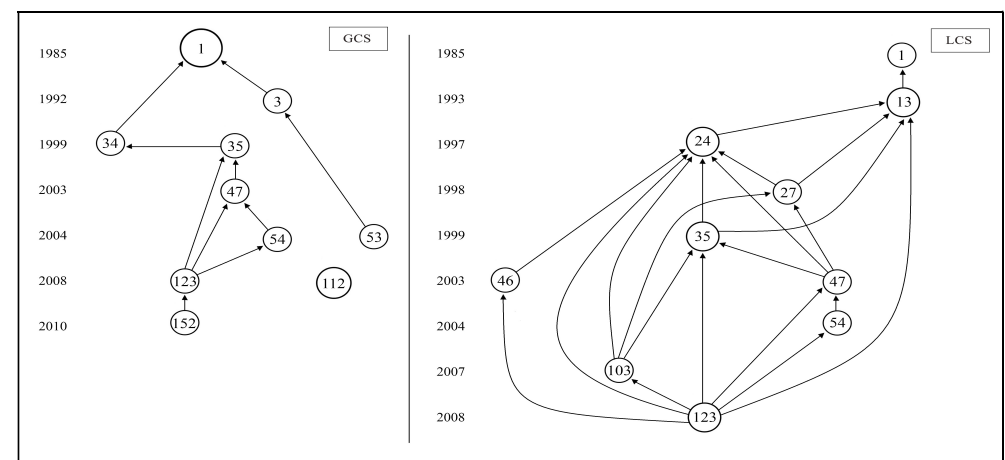

Figure 2. Top 10 of the most cited articles in the Web of Science ${ }^{\mathrm{TM}}$ (GCS) and the most cited by selected articles (LCS), among the selection set (1985-2016). 1 - Nickel JC, 1985, Antimicrob Agents Ch, V27, P619; 3 - Passerini L, 1992, Crit Care Med, V20, P665; 13 - Stickler D, 1993, Urol Res, V21, P407; 24 - Morris NS, 1997, Brit J Urol, V80, P58; 27 - Morris NS, 1998, J Hosp Infect, V39, P227; 34 - Adams JL, 1999, Appl Environ Microb, V65, P4285; 35 - Morris NS, 1999, World J Urol, V17, P345; 46 - Stickler DJ, 2003, Lancet, V361, P1435; 47 - Saint S, 2003, Infect Dis Clin N Am, V17, P411; 53 - Trautner BW, 2004, Arch Intern Med, V164, P842; 54 - Trautner BW, 2004, Am J Infect Control, V32, P177; 103 - Macleod SM, 2007, J Med Microbiol, V56, P1549; 112 - Roe D, 2008, J Antimicrob Chemoth, V61, P869; 123 - Stickler DJ, 2008, Nat Clin Pract Urol, V5, P598; 152 - Francolini I, 2010, Fems Immunol Med Mic, V59, P227.

Figure 1 shows the relationship between the texts of the journals referring to the ten articles most cited in the GCS group, covering the period from 1985 to 2010, and the LCS group, covering the period from 1985 to 2008 . It is worth mentioning the presence of articles 1, 35 and 54 in both groups.

\section{DISCUSSION}

It is noteworthy that researches entitled "authority article" or "base article" that are the main references of others who also receive large amounts of citations (SANTOS et al., 2014). They were: the articles number 1(NICKEL et al, 1985), 3(PASSERINI, et al 1992) and 13(STICKLER et al, 1993) shown in Figure 1. In addition to the figure of the authority article, there are also "hub articles" or "connecting articles" that condense important 
information from previous works connecting these to more recent ones, also receiving large amounts of citations (MORRIS, STICKLER, WINTERS, 1997).

Article 1 (SANTOS et al., 2014), much cited and presented in Figure 1 in the GCS and LCS, evaluated the ability of the antimicrobial tobramycin to act against the biofilms of Pseudomonas aeruginosa adhered in a latex urinary catheter under controlled conditions of artificial urine. The planktonic cells of $P$. aeruginosa were completely killed with tobramycin, but when exposed as biofilms they showed resistance to this type of antibiotic even at high concentrations. In the relationship shown in Figure 1 in the GCS, article number 3 (13), although it does not address biofilm formation in urinary catheters, it is cited in the papers listed in this bibliometric survey.

The survey number 13(MORRIS, STICKLER, WINTERS, 1997), in Figure 1 in the LCS, reported the presence of biofilm encrustations by Proteus mirabilis on long-term urinary catheters. Biofilms were visible on the luminal surfaces of 69 catheters (out of a total of 75). Of the 18 catheters colonized by $P$. mirabilis, 10 are composed of pure cultures of the species and 8 with up to 3 additional species. They also observed struvite and hydroxyapatite inlays with partial or total occlusion of catheter lumens and a low number of catheters colonized by non-urease species.

Article 24 (MORRIS, STICKLER, WINTERS, 1997), in Figure 1 in the LCS, evaluated the resistance of 18 types of urinary long-stay catheters for obstruction by biofilm fouling by $P$. mirabilis. The research used a bladder model containing sterile artificial urine inoculated with a clinical strain of $P$. mirabilis isolated from an inbuilt catheter. Mean blocking times ranged from 21 $\mathrm{h}$ for the Bard Hydrogel / Silver Coated Latex type catheter coated with silver at $56 \mathrm{~h}$ for the Eschmann Folatex S All Silicone silicone catheter. The complete blockade usually occurred $2 \mathrm{~cm}$ below the "eye" hole. The research demonstrated that none of the types of catheters evaluated, including those coated with hydrogel or silver, were able to resist biofilm fouling by $P$. mirabilis.

The following year, 2 of the three authors mentioned above performed a survey, represented by the number 27 (MORRIS, STICKLER, 1998) in Figure 1 in the LCS, which verified inlay and blockage of 4 types of urinary catheters. The research used the same catheterized bladder model, but containing human urine, which was inoculated with a strain of $P$. mirabilis isolated from an embedded catheter. Mean catheter locking times ranged from 17.7 hours for the silver coated latex type, 34 hours for the hydrogel coated latex, 38 hours for the silicone coated latex, and 47 hours for the whole silicone. The authors emphasized the need to develop a urinary catheter surface that resists biofilm fouling by $P$. mirabilis.

In the article number 34 presented in Figure 1 (ADAMNS, MCLEAN, 1999), referenced by article number 35 (much quoted in GCS), it was hypothesized that slow growth is an important aspect of bacterial biofilm physiology. Elimination of the slow-growing activated gene (rpoS) considerably reduces the growth capacity of Escherichia coli in biofilms and has little effect on the growth of planktonic bacteria. For this, it was investigated whether the absence of rpoS could affect the formation of biofilm by $E$. coli in different experimental conditions.

The study 35 'MORRIS, STICKLER, MCLEAN, 1999) was a review of the literature on biofilms and their role in UTIs, especially those associated with urinary catheters. It was found that the risk of UTI was related to the duration of catheterization and the standard of care with catheter use. Bacteriuria rates ranged from 10 to $50 \%$ in patients using a short-term urinary catheter (1 to 7 days), while those who remained with a catheter for 28 days or longer were indiscriminately infected. The bacteria Providencia stuartii, $P$. mirabilis, $P$. aeruginosa and Klebsiella pneumoniae were the most frequently and persistently isolated in the urinary tract.

The study 46 (STICKLER, JONES, RUSSEL, 2003) aimed to determine in vitro the ability of triclosan to diffuse through the flask and examine its ability to prevent urinary catheter embedding by $P$. mirabilis. Inflated catheters with triclosan solution inserted into sterile bladder models were maintained with sterile artificial urine for 24 hours. Antibacterial concentrations of triclosan may diffuse through the inflation line of the catheter and balloon into the urine. Triclosan can control urinary $\mathrm{pH}$ by preventing alkaline conditions that precipitate fouling. Thus, the catheters treated with triclosan drained freely for at least 7 days and showed no sign of scaling at the end of the experiment.

Other literature review research (SAINT, CHENOWETH, 2003) has revealed the duration of urinary catheterization as the most crucial risk factor for infection, so permanent urethral catheterization should be avoided or at least limited whenever possible. Similar reviews of literature review on the pathogenesis and prevention of catheter-associated infections (TRAUTNER; DAROUICHE, 2004a; TRAUTNER; DAROUICHE, 2004b) describe the 
formation of biofilms on the surfaces of the catheters and the strategies and factors that make it difficult to prevent infection, both for intravascular catheters and urinary catheters. It was concluded that there are no proven effective strategies for the prevention of catheter-associated UTI in chronically catheterized persons because of the high numbers and various types of organisms present on the site. As for intravascular catheters, impregnating them with antimicrobials is a useful strategy for infection control measures.

Research (MACLEOD, STICKLER,2007), examined by means of laboratory bladder models the associations between $P$. mirabilis and the time of fouling of the microorganisms present in 106 urinary catheter biofilms. It was observed that when $P$. stuartii or $K$. pneumoniae commonly developed with $P$. mirabilis. The bacteria ability to embed and block catheters was not affected. However, when Enterobacter cloacae, Morganella morganii or $P$. aeruginosa colonized the catheters, $P$. mirabilis was rarely found in the biofilm, significantly increasing catheter blockage time. It was concluded that while there is some degree of antagonism between $P$. mirabilis and some other urinary tract microorganisms, there is also a high degree of scale susceptibility in the catheters leading to a consequent blockage of them.

Another research (ROE et al, 2008) describes a method for coating polyamide urinary catheters with low toxicity silver nanoparticles at low temperatures and provides evidence for the antimicrobial properties of such catheters and the safety of their use in animals (experiment by testing the toxicity of silver in laboratory rats). Catheters coated with silver nanoparticles showed significant in vitro antimicrobial activity and prevented the formation of E. coli, Enterococcus, Staphylococcus aureus, coagulase-negative staphylococci, $P$. aeruginosa and Candida albicans. It was concluded that silver release is active against microorganisms most commonly found in hospital infections and accumulates predominantly at the site of catheter insertion.

Another literature review (STICKLER, 2008) emphasized that strong epidemiological and experimental evidences point out $P$. mirabilis as the main responsible for the formation of crystalline biofilms in long-stay urinary catheters, since its production of urease is much faster than in other species. The last article, also of review of the literature (FRANCIOLINI, DONELLI, 2010), found that there are three possible strategies that can prevent or minimize the formation of biofilms in urinary catheters. The first of these is the inhibition of microbial adherence to the surface of the device by altering the hydrophobicity (coating with hydrophilic polymers). The second strategy is the interference in the signal of connection between the molecules that form the biofilm, modulating its development. Finally, the third strategy is the disintegration of the biofilm matrix, through the use of substances capable of destroying its physical integrity and consequent loss of the protective barrier and exposure of microbial cells to antimicrobials. These findings are in agreement with more recent studies on biofilm prevention and formation, reinforcing the originality of the findings (SOUSA et al, 2017a; GÜRTLER et al, 2019).

\section{CONCLUSIONS}

International research shows a diversified production regarding the formation and prevention of biofilms in urinary catheters. The approach of the theme tends to continue growing in the next years and there is a predominance of in vitro research, followed by literature reviews.

The bibliometric analysis highlighted the existence of a great interrelationship in the citations identified in the texts, allowing a better understanding of the biofilms in urinary catheters, and the importance of adopting more efficient strategies to be developed and applied.

RESUMO: Mapear a produção científica acerca da formação e prevenção de biofilmes em cateteres urinários. Trata-se de uma pesquisa bibliométrica, exploratória e descritiva, realizada no Web of Science ${ }^{\mathrm{TM}}$, em três estágios, e utilizando o software HistCite ${ }^{\mathrm{TM}}$. Nesse sentido, foram utilizados os descritores "Biofilme*" E "Cateter Urinário*" no período de 1945 a 2016. Foram encontrados 329 artigos sobre biofilme em cateter urinário no período de 1985 a 2016. Estes artigos foram escritos por 1.262 autores de 452 instituições localizadas em 50 países. A relação entre os 15 artigos selecionados, os mais impactantes, evidencia a existência de pesquisas experimentais; a maioria delas foi in vitro. $\mathrm{O}$ controle da formação de biofilme nos cateteres urinários permanece como um grande desafio na área da saúde, pois são necessárias novas formas de melhorar a prevenção e a minimização desse fenômeno.

PALAVRAS-CHAVES: Biofilmes. Bibliometria. Cateteres Urinários. 


\section{REFERENCES}

ADAMS, J. L.; MCLEAN, R. J. C. Impact of rpoS deletion on Escherichia coli biofilms. Appl. Environ. Microbiol., v. 65, n. 9, p. 4285-4287, 1999. https://doi.org/10.1128/AEM.65.9.4285-4287.1999

BATISTA, O., et al. Cateter urinário: o tempo de exposição e calibre podem influenciar na formação de biofilme? Acta paul. enferm., São Paulo, v. 31, n. 5, p. 535-541, 2018. DOI: http://dx.doi.org/10.1590/19820194201800074 .

CRONIN, B. Bibliometrics and beyond: some thoughts on web-based citation analysis. Journal of Information science, v. 27, n. 1, p. 1-7, 2001. DOI: 10.1177/016555150102700101.

DIEM, A.; WOLTER, S. C. The use of bibliometrics to measure research performance in education sciences. Research in higher education, v. 54, n. 1, p. 86-114, 2013. DOI: 10.1007/s11162-012-9264-5.

FRANCOLINI, I; DONELLI, G. Prevention and control of biofilm-based medical-device-related infections. FEMS Immunology \& Medical Microbiology, v. 59, n. 3, p. 227-238, 2010. DOI: 10.1111/j.1574695X.2010.00665.x.

FURLAN, M. C. R., et al. Correlation among monitoring methods of surface cleaning and disinfection in outpatient facilities. Acta Paul Enferm, v. 32, n. 3, p. 282-9, 2019a. DOI: 10.1590/1982-0194201900039.

FURLAN, M. C. R., et al. Evaluation of disinfection of surfaces at an outpatient unit before and after an intervention program. BMC infectious diseases, v. 19, n. 1, p. 355, 2019b. DOI:10.1186/s12879-019-3977-4

GÜRTLER, N., et al. Prosthetic valve endocarditis caused by Pseudomonas aeruginosa with variable antibacterial resistance profiles: a diagnostic challenge. BMC infectious diseases, v. 19, n. 1, p. 530, 2019. DOI: $10.1186 / \mathrm{s} 12879-019-4164-3$.

KOSKINEN, J., et al. How to use bibliometric methods in evaluation of scientific research? An example from Finnish schizophrenia research. Nordic journal of psychiatry, v. 62, n. 2, p. 136-143, 2008. https://doi.org/10.1080/08039480801961667

MACLEOD, S. M; STICKLER, D. J. Species interactions in mixed-community crystalline biofilms on urinary catheters. Journal of medical microbiology, $\quad$ v. $56, \quad$ n. $11, \quad$ p. 1549-1557, $2007 . \quad$ DOI: https://doi.org/10.1099/jmm.0.47395-0

MATOS, M., et al. Infection control is a safety indication: Discussions based on the student's perspective. Revista de Pesquisa: Cuidado é fundamental online, v. 10, n. 3, p. 640-646, 2018. DOI: http://dx.doi.org/10.9789/2175-5361.2018.v10i3.640-646

MORRIS, N. S.; STICKLER, D.J.; WINTERS, C. Which indwelling urethral catheters resist encrustation by Proteus mirabilis biofilms?. British journal of urology, v. $80, \quad$ n. $1, \quad$ p. $58-63,1997$. https://doi.org/10.1046/j.1464-410X.1997.00185.x

MORRIS, N. S.; STICKLER, D. J. Encrustation of indwelling urethral catheters by Proteus mirabilis biofilms growing in human urine. Journal of Hospital Infection, v. 39, n. 3, p. 227-234, 1998. https://doi.org/10.1016/S0195-6701(98)90262-6

MORRIS, N. S.; STICKLER, D. J; MCLEAN, R. J. The development of bacterial biofilms on indwelling urethral catheters. World journal of urology, v. 17, n. $6, \quad$ p. $345-350,1999$. https://doi.org/10.1007/s003450050159 
NICKEL, J. C., et al. Tobramycin resistance of Pseudomonas aeruginosa cells growing as a biofilm on urinary catheter material. Antimicrobial agents and chemotherapy, v. 27, n. 4, p. 619-624, 1985. https://doi.org/10.1128/AAC.27.4.619

PASSERINI, L., et al. Biofilms on indwelling vascular catheters. Critical care medicine, v. 20, n. 5, p. 665673, 1992. https://doi.org/10.1097/00003246-199205000-00020

ROE, D., et al. Antimicrobial surface functionalization of plastic catheters by silver nanoparticles. Journal of antimicrobial chemotherapy, v. 61, n. 4, p. 869-876, 2008. DOI: https://doi.org/10.1093/jac/dkn034

SAINT, S.; CHENOWETH, C. E. Biofilms and catheter-associated urinary tract infections. Infectious disease clinics of North America, v. 17, n. 2, p. 411-432, 2003. DOI: https://doi.org/10.1016/S0891-5520(03)00011-4

SANTOS, J. L. S., et al. Innovation and organizational knowledge: A bibliometric mapping of scientific publications até 2009. Organizações em contexto, v. 7, n. 13, p. 31-58, 2011a. https://doi.org/10.15603/19828756/roc.v7n13p31-58

SANTOS, J. L. S., et al. Mapping of Academic and Scientific Publications on Organizational Memory. Proceedings of the XXXV ANPAD Meeting - National Meeting of the National Association of Graduate Studies and Research in Administration; 2011 Sept 4-7; Rio de Janeiro, RJ, Brazil. Rio de Janeiro: ANPAD; $2011 \mathrm{~b}$.

SANTOS, J. L. S., et al. Inter-organizational Cooperation Networks: Analysis of the Scientific Production in the Web of Science (1981-2013). Proceedings of the XVII SemeAd - Seminars in Aministration; 2014 Oct 29-31; São Paulo, SP, Brazil. São Paulo: FEA-USP; 2014.

SANTOS-JUNIOR, A. G., et al. Effectiveness of Surface Cleaning and Disinfection in a Brazilian Healthcare Facility. The open nursing journal, v. 12, p. 36, 2018. DOI: 10.2174/1874434601812010036.

SOUSA, A. F. L., et al. Prevenção da formação de biofilmes em marcapassos artificiais: é viável?. Acta Paulista de Enfermagem, v. 30, n. 6, p. 644-650, 2017a. DOI: http://dx.doi.org/10.1590/1982-0194201700085

SOUSA, A. et al. Perfil epidemiológico das infecções hospitalares causadas por procedimentos invasivos em unidade de terapia intensiva. Revista Prevenção de Infecção e Saúde, v. 2, n. 1-2, p. 11-17, $2017 b$. https://doi.org/10.26694/repis.v2i1-2.6048

STICKLER D, et al. Proteus mirabilis biofilms and the encrustation of urethral catheters. Urological research, v. 21, n. 6, p. 407-411, 1993. https://doi.org/10.1007/BF00300077

STICKLER, D. J.; JONES, G. L.; RUSSELL, A. D. Control of encrustation and blockage of Foley catheters. The Lancet, v. 361, n. 9367, p. 1435-1437, 2003. DOI: https://doi.org/10.1016/S01406736(03)13104-2

STICKLER, D. J. Bacterial biofilms in patients with indwelling urinary catheters. Nature Reviews Urology, v. 5, n. 11, p. 598, 2008. https://doi.org/10.1038/ncpuro1231

TRAUTNER, B. W.; DAROUICHE, R. O. Catheter-associated infections: pathogenesis affects prevention. Archives of internal medicine, v. 164, n. 8, p. 842-850, 2004a DOI: 10.1001/archinte.164.8.842

TRAUTNER, B. W.; DAROUICHE, R. O. Role of biofilm in catheter-associated urinary tract infection. American journal of infection control, v. 32, n. 3, p. 177-183, 2004b DOI: https://doi.org/10.1016/j.ajic.2003.08.005 